\title{
Primary ovarian ectopic pregnancy: early diagnosis is the key
}

\section{Priyanka H. Vora*, Rana A. Choudhary, Kedar N. Ganla}

Department of Reproduction, Ankoor Fertility Clinic, Mumbai, Maharashtra, India

Received: 26 July 2019

Revised: 09 October 2019

Accepted: 25 October 2019

\section{*Correspondence:}

Dr. Priyanka H. Vora,

E-mail: priyav865@gmail.com

Copyright: (C) the author(s), publisher and licensee Medip Academy. This is an open-access article distributed under the terms of the Creative Commons Attribution Non-Commercial License, which permits unrestricted non-commercial use, distribution, and reproduction in any medium, provided the original work is properly cited.

\section{ABSTRACT}

Ectopic pregnancy means implantation of the embryo outside the uterine cavity. It may occur in the fallopian tubes, ovaries or the cervix. Primary ovarian ectopic is a very rare condition. In such cases preservation of ovary is extremely important, particularly in patients with infertility. We report a case of primary ovarian ectopic which was managed conservatively in a patient of primary infertility. Preservation of ovary is extremely important, particularly in patients with infertility.

Keywords: Conservative treatment, Ectopic pregnancy, Medical management, Methotrexate, Primary ovarian ectopic

\section{INTRODUCTION}

Primary ovarian ectopic pregnancy, i.e. implantation of the blastocyst outside the endometrium of the uterine cavity, occurs in $1.9 \%$ of reported pregnancies. ${ }^{1}$ Primary Ovarian ectopic pregnancy is a very rare entity accounting for 1 in 25000 to 1 in 40000 pregnancies. $^{2}$ Ovarian ectopic pregnancy is an extremely rare type of ectopic pregnancy and very few studies have been reported on the same.

\section{CASE REPORT}

A 32-year-old female married since 5 years on treatment for primary infertility conceived in the $2^{\text {nd }}$ cycle of controlled ovarian hyperstimulation with oral aromatase inhibitor (letrozole $2.5 \mathrm{mg}$ ). Her first Beta hCG value done at around 5 weeks after her last menses after a positive urine pregnancy test and was $1851 \mathrm{IU} / \mathrm{ml}$. Her Serum Beta hCG levels repeated after 48 hours were $3132 \mathrm{IU} / \mathrm{ml}$. However, at 6 weeks of gestation the patient reported to our clinic with complains of vaginal spotting.

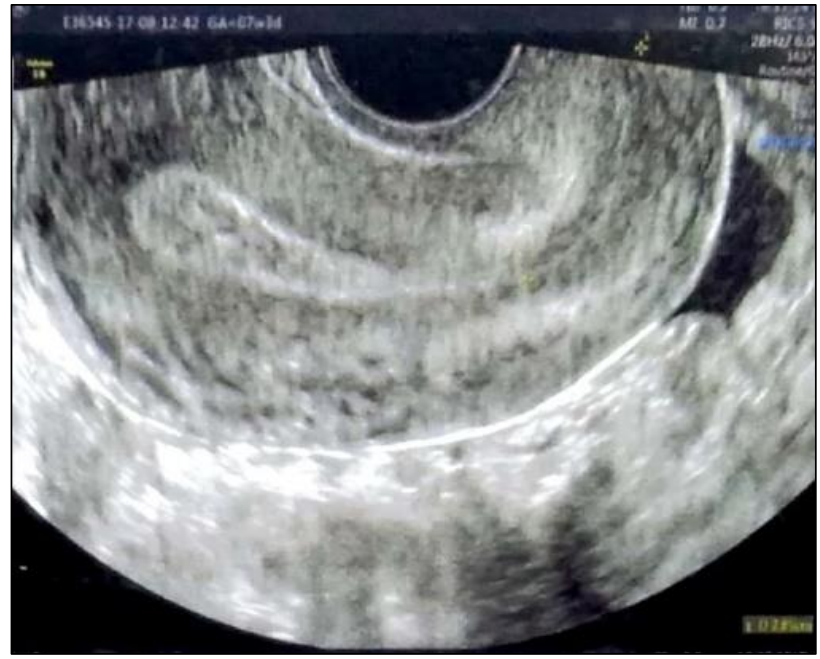

Figure 1: Empty uterine cavity.

On general examination her vitals were stable. Per abdomen examination revealed no tenderness, guarding or rigidity. Gynecological examination revealed mild 
right adnexal tenderness. Transvaginal scan showed an empty uterine cavity with a bulky right ovary (3.0x2.4 $\mathrm{cm}$ ) and a very small $2 \times 3 \mathrm{~mm}$ sac like structure adjacent to the corpus luteum. Doppler study confirmed increased vascularity in the right ovary which was suggestive of primary ovarian ectopic pregnancy in the right ovary (Figure 1, 2, 3). Laboratory tests for complete blood count, liver and renal function tests were within normal limits. The repeated serum beta HCG was $6386 \mathrm{IU} / \mathrm{ml}$.

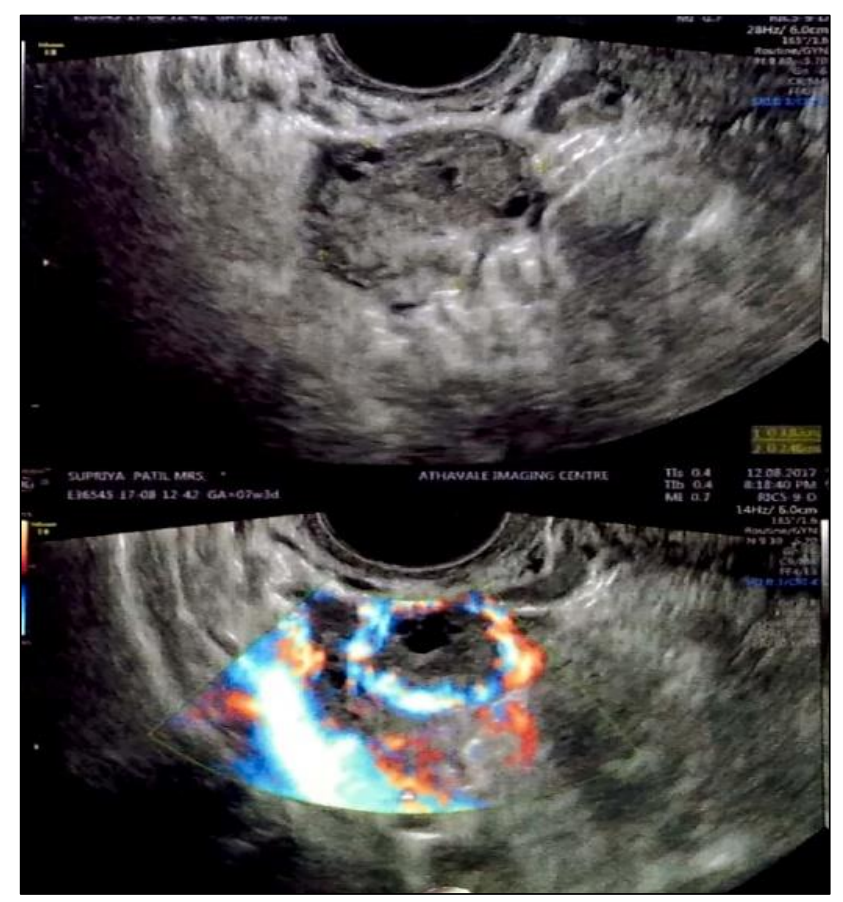

Figure 2: USG Doppler showing bulky right ovary and increased flow with "ring of fire" appearance suggestive of ectopic pregnancy in the right ovary.

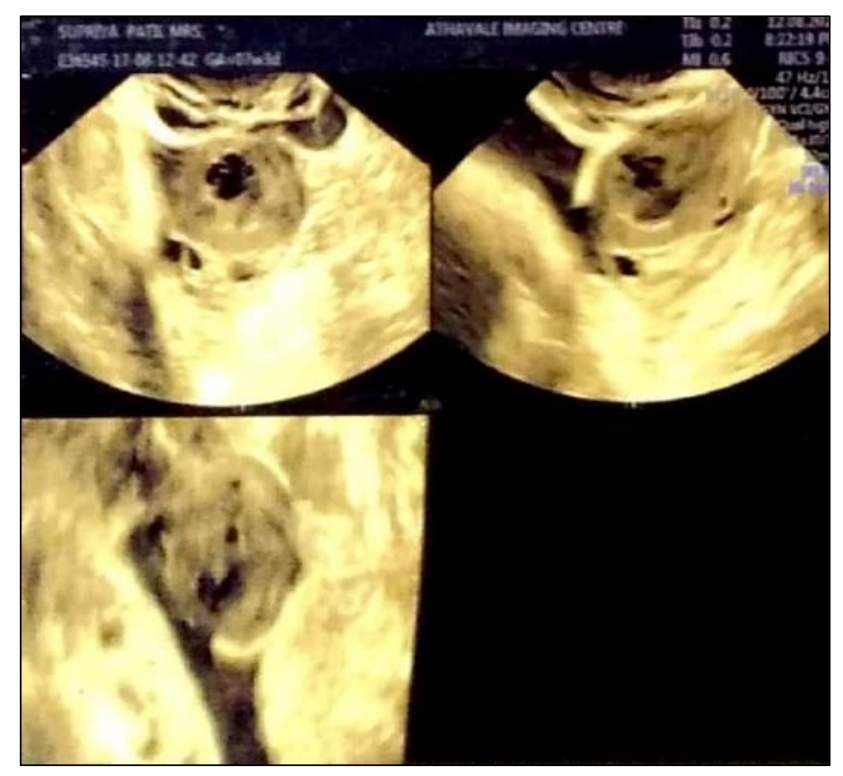

Figure 3: TVS pelvis with 3D view of the right ovary with sac like structure suggestive of right ovarian ectopic pregnancy.
Table 1: Serial change in beta HCG values during pregnancy.

\begin{tabular}{|ll|}
\hline Day of blood test & Serum beta HCG $(\mathrm{IU} / \mathrm{ml})$ \\
\hline Day 0 & $6386 \mathrm{IU} / \mathrm{mL}$ \\
\hline Day 4 & $3887 \mathrm{IU} / \mathrm{ml}$ \\
\hline Day 7 & $436 \mathrm{IU} / \mathrm{ml}$ \\
\hline Day 14 & $2.15 \mathrm{IU} / \mathrm{ml}$ \\
\hline
\end{tabular}

As the patient was clinically stable, a conservative approach was offered after discussing with the patient and his husband and their consent taken. Injection Methotrexate $(1 \mathrm{mg} / \mathrm{kg}) 50 \mathrm{mg}$ single dose was given intramuscular alternating with leucovorin rescue of 0.1 $\mathrm{mg} / \mathrm{kg}$ weekly for 2 doses. Serial serum beta HCG values were performed, and post methotrexate reading showed a decline to $3887 \mathrm{IU} / \mathrm{ml}$ on day 4 to $1026 \mathrm{IU} / \mathrm{ml}$ on day 7 , $436 \mathrm{IU} / \mathrm{ml}$ one week later and finally 2.15 (i.e. negative) after 2 weeks as seen in Table 1 . Thus, the ectopic pregnancy was treated with medical management conserving the patient's fertility.

\section{DISCUSSION}

Primary ovarian ectopic pregnancy is an extremely rare type of ectopic pregnancy and very few studies have been reported on the same. Zhu Q et al, reported IVF-ET and IUD use as one of the major risk factors for ovarian ectopic pregnancy. Other risk factors also include previous adnexal surgery, a positive reaction to Chlamydia Trachomatis., ${ }^{3,4}$ As a matter of fact, an intrauterine contraceptive device is found in $14 \%$ to $30 \%$ of patients with a nonovarian extra- uterine pregnancy, while it is found in proportions ranging from $57 \%$ to $90 \%$ of patients with a primary ovarian pregnancy. ${ }^{5}$ Classical triad of ectopic pregnancy i.e. amenorrhea, pain abdomen and vaginal bleeding is present in many cases. Although the ovary can accommodate itself more readily than the tube to the expanding pregnancy but $75 \%$ of ovarian gestation rupture in the early first trimester and are usually misdiagnosed as corpus luteal hemorrhage. ${ }^{6}$ Term healthy live birth out of ovarian pregnancy is very rare. ${ }^{7}$

Role of ultrasound in diagnosis of ovarian gestation has been described by various authors. The following sonographic diagnostic criteria have been suggested: a wide echogenic ring with an internal echo lucent area on the ovarian surface; the presence of ovarian cortex, including corpus luteum or follicles around the mass; and the echogenicity of the ring usually greater than that of the ovary itself. ${ }^{8}$ The diagnostic criteria for primary ovarian ectopic were established in 1878 by Spiegelberg based primarily on the identification of an embryonic sac within the ovary and the localization of conception products therein but are obsolete now with the advent of ultrasound in infertility. Most of these patients present with ruptured ectopic and are in circulatory collapse so preoperative diagnosis of ovarian ectopic on sonography is not easily made. Intraoperative diagnosis is difficult many a times as ovarian pregnancy mimics a 
hemorrhagic corpus luteal cyst. ${ }^{6}$ Since majority of these patients present with ruptured pregnancy and in a collapsed state, treatment of choice is laparoscopic (Ovarian preservation with excision of ectopic pregnancy can be achieved using techniques commonly used for ovarian cystectomy) or laparotomy with resection of sac and hemostasis. Medical and conservative treatments have also been introduced in recent years to prevent ovarian tissue loss, pelvic adhesions and to preserve the patient's fertility. These include administration of mifepristone for patients diagnosed using a transvaginal USG, parenteral prostaglandin F2a and MTX treatment for non-ruptured cases detected with laparoscopy. ${ }^{6,9}$ The cases in which the gestational sac is lower than $30 \mathrm{~mm}$, without fetal cardiac activity, and less than 6-weeks old, MTX treatment is superior to surgery as it does not disturb fertility. ${ }^{10}$ Our patient was a case of primary infertility, and was diagnosed early, hence a trial of medical management using methotrexate was given.

In a multicenter retrospective study by Boots et al, Methotrexate did not influence ovarian reserve, response to gonadotropin stimulation, and clinical pregnancy or live birth rate after ART. Methotrexate remained a safe and effective treatment option for women with asymptomatic ectopic pregnancies. ${ }^{11}$ Literature suggests there is a high rate of successful subsequent pregnancy and a low rate of subsequent ectopic pregnancy or of infertility. ${ }^{12}$

\section{CONCLUSION}

Incidence of ovarian pregnancy is on rise due to increased incidence of infertility and use of assisted reproductive techniques. Ultrasonography can detect ovarian gestations in unruptured cases but cannot easily differentiate ovarian from other tubal gestation in ruptured state. Medical management proves effective in early gestations to preserve future fertility of patients and must be offered in selected cases especially in infertile women.

Funding: No funding sources Conflict of interest: None declared Ethical approval: Not required

\section{REFERENCES}

1. Leite JD, Fraietta R, Elito Júnior J. Local management with methotrexate of cesarean scar ectopic pregnancy with live embryo guided by transvaginal ultrasound: a case report. 2016;62(2):184-5.

2. Hertig AT. Discussion of Gerin-Lojoie L. Ovarian pregnancy. Am J Obstet and Gynecol. 1951;62:920.

3. Spigelberg O. Casusistik der movarialschwangerschaft. Arch Gynecol. 1878;13:73.

4. Zhu Q, Li C, Zhao WH, Yuan JJ, Yan MX, Qin GJ, et al. Risk factors and clinical features of ovarian pregnancy: a case-control study. BMJ Open. 2014;4(12):1-7.

5. Scutiero G, Di Gioia P, Spada A, Greco P. Primary ovarian pregnancy and its management. JSLS J Soc Laparoendosc Surg. 2012;16(3):492-4.

6. Hallatt JG. Primary ovarian pregnancy: a report of twenty-five cases. Am J Obstet Gynecol. 1982;143(1):55-60.

7. Studziński Z, Branicka D, Filipczak A, Oliński K. Prolonged ovarian pregnancy: a case report. Ginekologia Polska. 1999;70(1):33-5.

8. Comstock C, Huston K, Lee W. The ultrasonographic appearance of ovarian ectopic pregnancies. Obstet Gynecol. 2005;105(1):42-5.

9. Lehfeldt H, Tietze C, Gorstein F. Ovarian pregnancy and the intrauterine device. Am J Obstet Gynecol. 1970;108(7):1005-9.

10. Annunziata N, Malignino E, Zarcone R. Ovarian pregnancies treated with methotrexate. Panminerva Medica. 1996;38(3):190-2.

11. Boots CE, Hill MJ, Feinberg EC, Lathi RB, Fowler SA, Jungheim ES. Methotrexate does not affect ovarian reserve or subsequent assisted reproductive technology outcomes. J Assist Reprod Genet. 2016;33(5):647-56.

12. Koo YJ, Choi HJ, Im KS, Jung HJ, Kwon YS. Pregnancy outcomes after surgical treatment of ovarian pregnancy. Int $\mathrm{J}$ Gynecol Obstet. 2011;114(2):97-100.

Cite this article as: Vora PH, Choudhary RA, Ganla KN. Primary ovarian ectopic pregnancy: early diagnosis is the key. Int J Reprod Contracept Obstet Gynecol 2019;8:5043-5. 